\title{
DRYING CHARACTERISTIC OF RAMMED EARTH WITH ILLITIC-KAOLINITIC CLAY CONTENT
}

\author{
Tereza Otcovská*, Barbora Mužíková, Pavel Padevět \\ Czech Technical University in Prague, Faculty of Civil Engineering, Thákurova 7, 16629 Prague 6, Czech \\ Republic \\ * corresponding author: tereza.otcovska@fsv.cvut.cz
}

\begin{abstract}
Clay is a traditional construction material which has got to background with introduction of modern materials to building practice. There is no proper material available for clay constructions design due to lack of proper examination of its mechanical properties. This paper focuses on drying rate of rammed earth. Drying is a primary way in which clay gets its strength. It is thus essential to know a duration needed to a construction to get dry. After pass of this time the maximum strength is attained and it is possible to load a construction. Properties of unburned clay are dependent on clay mix composition. In this contribution two sets of testing bodies with different composition are presented. As a bonding agent an illitic-kaolinite clay was used. It was presupposed that amount of used clay in clay mixture has major influence on the speed of drying and a final equilibrium moisture content. This presumption was disproved.
\end{abstract}

Keywords: Clay, Rammed Earth, Drying Rate, Water Coefficient, Load-bearing Structure.

\section{INTRODUCTION}

An unburned clay was commonly used construction material of the past. However, with the boom of new modern construction materials, unburned clay was pushed out from the business, and therefore the necessary scientific research of unburned clay mechanical properties was never performed [1-[5].

These days unburned clay returns to focus again generally for three reasons. First reason is reconstruction of already built clay buildings [6] 8 . Second, the unburned clay constructions are compatible with the principles of sustainable development [9, 10]. Third, unburned clay has a blessed impact on the internal micro-climate of the building and consequent improvement in the health of inhabitants [1, 3, 11.

One of the major methods of unburned clay manufacture is a ramming technology which this subscription concerns of. A principle of the method is ramming of earth layers into a framework. Rammed earth is mostly used for load bearing constructions and for that reason is important a knowledge of the earth drying speed [1, 3].

The drying speed of unburned clay is important because drying is the only process with which unburned clay gain its strength. It is thus necessary to know drying speed to be able to estimate the time that must pass from a manufacture to full construction load [1, 3, 9, 12].

The clay mixture consists of three basic components: sand, clay and water. The sand acts as a filling agent. The clay has a function of a bonding agent similarly as a cement in concrete. And water serves for activation of bonding properties of the clay and for proper processibility of clay mixture [1, 13, 15].
The clay mixtures that were experimentally examined and described in this contribution contain just these three basic components. No any additive nor additional bonding agent such as cement or lime were added to examined clay mixtures. The reason to exclude the additives was our effort to properly describe plain clay mixture.

It was proved that even plain unburned clay used as a construction material features long lifespan. It is true particularly for properly designed construction details. In some cases it was discovered that by adding of another organic bonding agents the result material strength decreased. That is crucial for load-bearing construction elements. Another reason why we concentrated on unburned clay without additives is a fact that addition of a cement or lime reduces positive influence of unburned clay to inner microclimate and raises environment load [3, 16, 17].

\section{TEST MIXTURE AND TEST BODIES MANUFACTURE}

Two types of clay mixtures were tested. The mixtures differed in sand to clay ratio and in amount of used water (water coefficient). The testing bodies were manufactured by ramming technology. The published results were measured minimally on six testing bodies of each mixture.

The used clay mixtures are composed from a sand (see Fig. 1), illitic-kaolinitic clay (see Fig. 2) and water (common tap water). A sand to clay ratio and water amount were prescribed for the both clay mixtures.

The behaviour of the clay mixture during drying and the speed of drying were studied in connection 


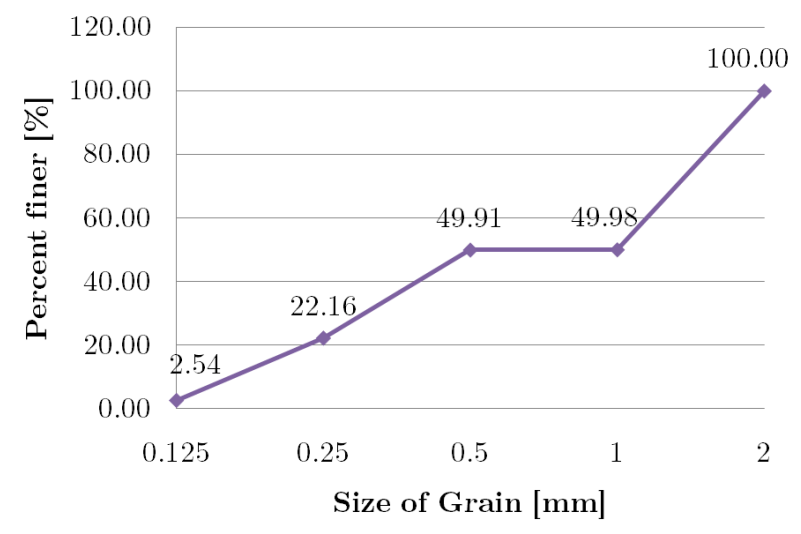

FigURE 1. Granularity curve.

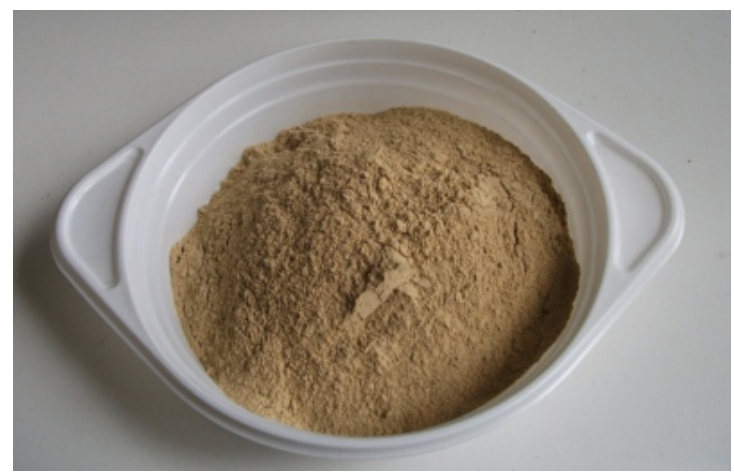

FiguRE 2. Illitic-kaolinitic clay.

with clay content and water content in the mixture. The clay mixture KRII contained $1 / 4$ more clay (bonding agent) than in the mixture KRIII. The mixture KRII was manufactured with water coefficient 0.37 . The mixture KRIII was manufactured using water coefficient 0.4 . The water coefficient is a ratio between weight of water and weight of clay. The actual clay mixture composition is declared in the Table 1 .

The test bodies were rammed using electric power hammer into steel moulds of size $40 \times 40 \times 160 \mathrm{~mm}$. Only the last layer was rammed manually (see Fig. 3 ).

Immediately after manufacture the testing bodies were put out of mold and weighted. After that the testing bodies were inserted into air-conditioned chamber, where constant temperature $\left(20^{\circ} \mathrm{C}\right)$ and relative humidity $(60 \%)$ are maintained (see Fig. 4). The testing bodies were left in the air-conditioned chamber until their humidity has settled (approximately 1 month).

\section{MeAsured Results}

The test bodies were held in the air-conditioned chamber and regularly weighted. Thus the decrease of their mass was measured (see Table 2, Fig. 6). A frequency of weighting was the highest in the first day after manufacture (approximately once per one to three hours). During the first day after manufacture the highest drop in weight was measured (approximately $90 \%$ from total drop of weight) (see Fig. 5 . Table 2 .

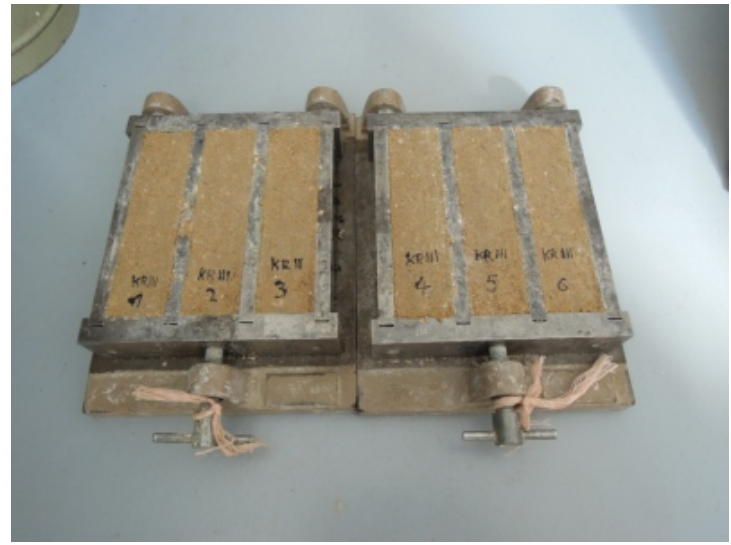

FiguRE 3. Production of the test bodies.

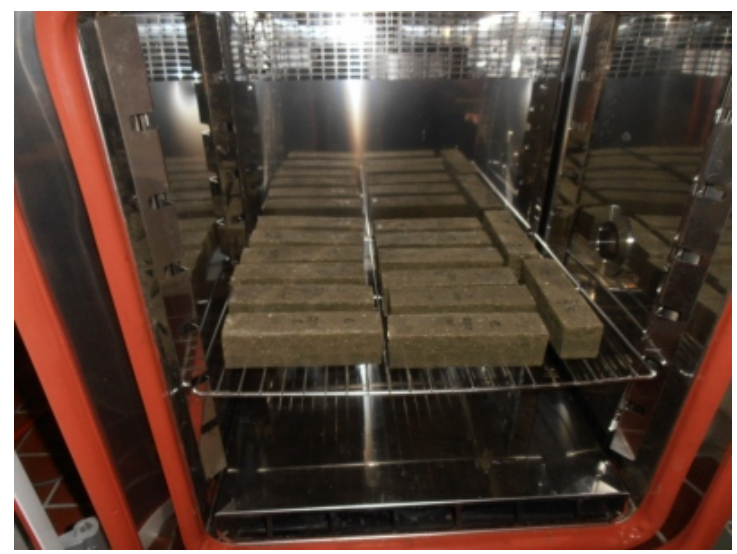

Figure 4 . Test bodies in the air-conditioning chamber.

The equation 1 was used for calculation of weight moisture content from the measured values. Initial weight moisture content of the both test body sets was $9.3 \%$. Time course of average value of weight moisture content is introduced in the Table 3 and in Figures 7 and 8 .

$$
w=\frac{m_{w}-m_{d}}{m_{d}}
$$

It can be seen in the Figures 7 and 8 that equilibrium moisture of KRIII set is $1.6 \%$ and thus higher than moisture of KRII which is $0.8 \%$ even though that KRIII set contains less clay that KRII set (see Table 1). This finding is surprising because it is generally believed that clay minerals bond water [1, 3, 13]. It was expected that equilibrium humidity of KRII set will be higher.

The reason why the equilibrium humidity is higher for clay mixture with lower clay ratio is probably that KRIII set was manufactured with higher water coefficient (see Fig. 9p).

It can be further conclude from carried on experiment that the speed of drying is independent on the amount of used clay. For the both mixtures the $90 \%$ of moisture content (calculated from the total moisture content drop) evaporated during the first 24 hours after manufacture. Equilibrium moisture content was 


\begin{tabular}{lcccc}
\hline Set & Clay & Sand/clay ratio & Water/clay ratio & Number of test bodies \\
\hline KRII & illite-kaolinitic & $75 / 25$ & 0.37 & 6 \\
KRIII & illite-kaolinitic & $80 / 20$ & 0.4 & 6 \\
\hline
\end{tabular}

TABLE 1. Composition of the clay mixture batches and number of test bodies.

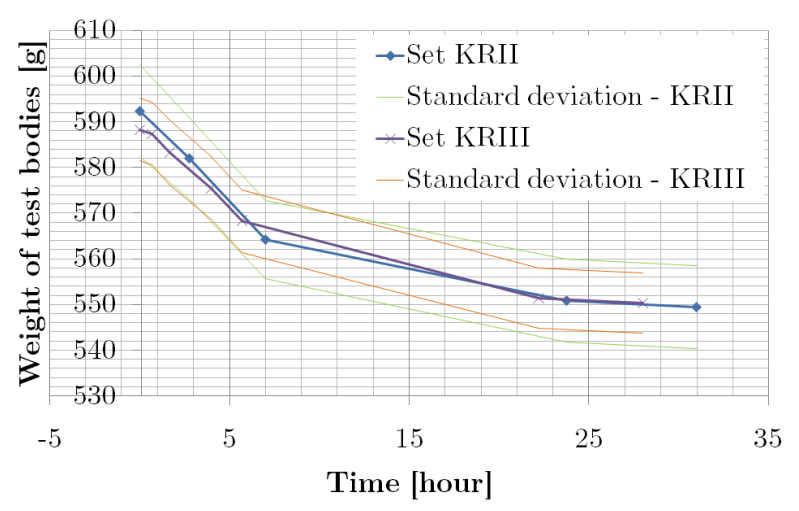

FIGURE 5. Time course of the test bodies weight after the first 30 hours from manufacture.

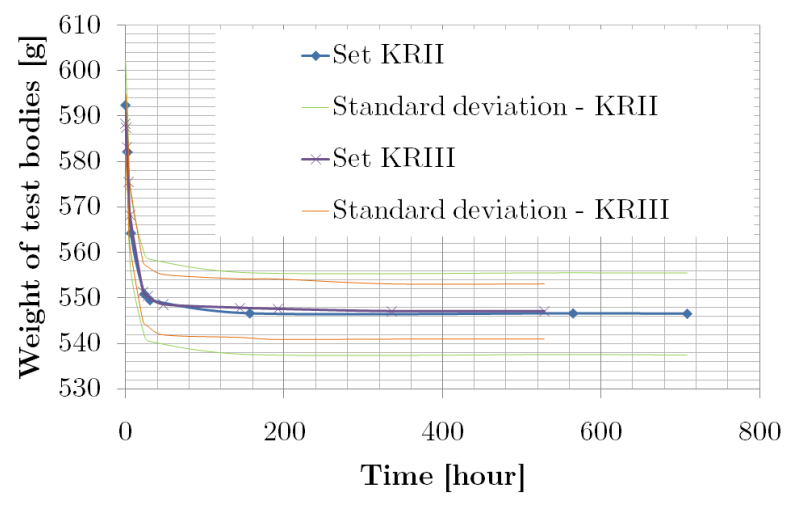

Figure 6. Time course of the test bodies average weight.

reached after approximately 25 days. The form coefficient of test bodies defined by equation 2 was 0.8889 .

$$
C_{s}=\frac{V_{t b}}{A_{t b}}
$$

\section{Conclusion}

The carried out experiment showed that the amount of used water in mixture can have more substantial influence to resulting equilibrium humidity than amount of used clay. However, it is necessary to verify this finding and state the actual influence in detail. It should be acomplished by testing another sets of clay mixtures that would be manufactured in wider range of sand/clay ratio and water/clay ratio. It is also necessary to focus on microstructure of tested material to reliably describe influence of water and clay ratios on unburned clay drying courses.

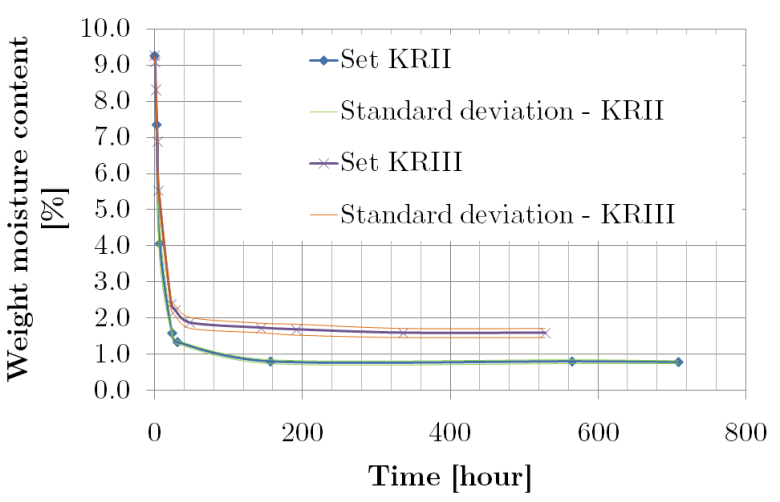

Figure 7. Time course of weight moisture content.

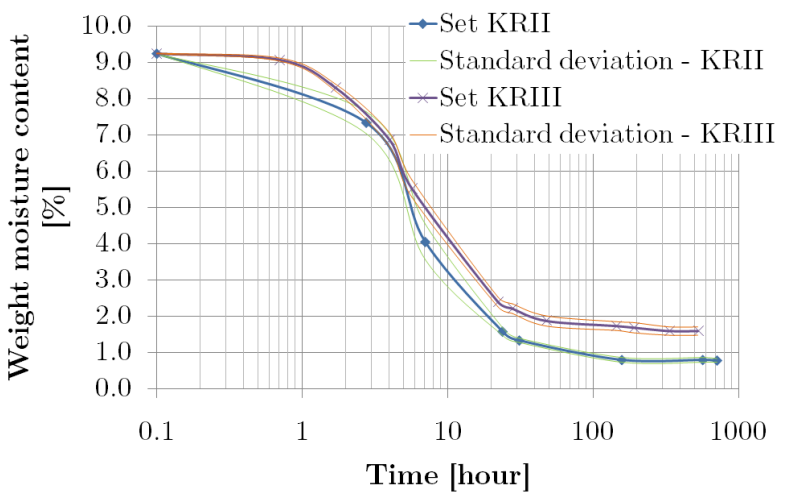

Figure 8. Time course of weight moisture content logarithmic scale of time

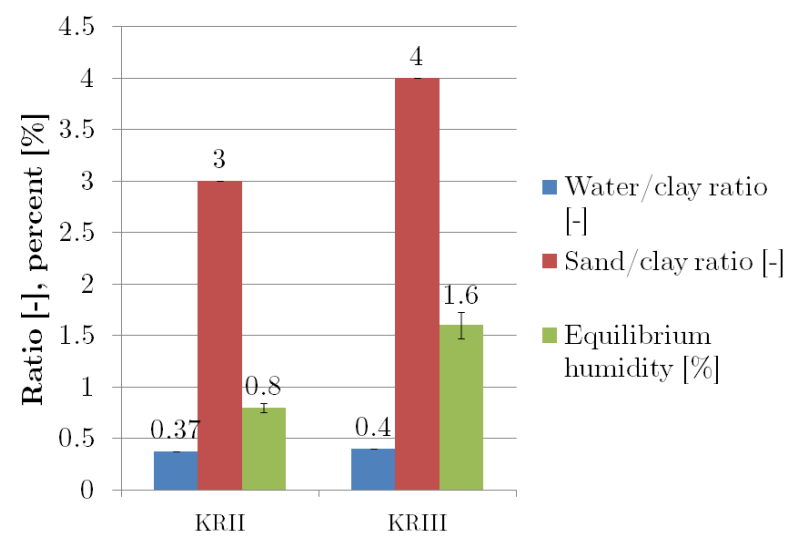

Figure 9. Ratio of the clay and water in mixture and resultant equilibrium humidity. 


\begin{tabular}{lcccccccccccccccc}
\hline \multirow{2}{*}{ Set } & \multicolumn{11}{c}{ 1 } & \multicolumn{11}{c}{ Time elapsed after manufacture [hour] } \\
& 0 & 0.7 & 1.7 & 3 & 4 & 7 & 22 & 24 & 28 & 31 & 48 & 144 & 157 & 192 & 528 & 709 \\
\hline KRII & 592 & - & - & 582 & - & 564 & - & 551 & - & 550 & - & - & 547 & - & - & 547 \\
KRIII & 588 & 587 & 583 & - & 575 & - & 551 & - & 550 & - & 549 & 548 & - & 548 & 547 & - \\
\hline
\end{tabular}

TABLE 2. Time course of the test bodies average weight [g].

\begin{tabular}{lcccccccccccccccc}
\hline \multirow{2}{*}{ Set } & \multicolumn{11}{c}{ Time elapsed from test bodies manufacture [hour] } \\
& 0 & 0.7 & 1.7 & 3 & 4 & 7 & 22 & 24 & 28 & 31 & 48 & 144 & 157 & 192 & 528 & 709 \\
\hline KRII & 9.3 & - & - & 7.3 & - & 4.1 & - & 1.6 & - & 1.3 & - & - & 0.8 & - & - & 0.8 \\
KRIII & 9.3 & 9.1 & 8.3 & - & 6.9 & - & 2.4 & - & 2.2 & - & 1.9 & 1.7 & - & 1.7 & 1.6 & - \\
\hline
\end{tabular}

TABLE 3. Time course of the test bodies average weight moisture content [\%].

The obtained results also indicate that the drying speed is not dependent on the amount of the clay in a clay mixture. For test bodies with form coefficient of 0.8889 the drying was almost complete (reaching of equilibrium humidity) after the first 24 hours.

\section{LIST OF SYMBOLS}

$w$ Weight moisture content [-]

$m_{m}$ Weight of damp sample [g]

$m_{d}$ Weight of dry sample [g]

$C_{s}$ Form coefficient [m]

$V_{t b}$ Volume of test body $\left[\mathrm{m}^{3}\right]$

$A_{t b} \quad$ Surface of test body $\left[\mathrm{m}^{2}\right]$

\section{ACKNOWLEDGEMENTS}

The financial support of this work by the Faculty of Civil Engineering, Czech Technical University in Prague (SGS project No. SGS16/201/OHK1/3T/11) is gratefully acknowledged. We would like to express our thanks to LB MINERALS, s.r.o. company for free supply of material necessary for experimental measurement and we would also like to express thanks to HELUZ cihláhřský průmysl v.o.s. for giving statistical data and information.

\section{REFERENCES}

[1] G. Minke. Building With Earth. Ökobuch Verlag, Staufen, 2006.

[2] ČSN 1168-1939 - Podmínky pro zednické a přidružené práce pozemních staveb, 1951.

[3] I. Žabičková. Hliněné stavby. Era 21, Brno, 2002.

[4] P. Stejskal. HELUZ cihlářský průmysl v. o. s. individual consultation, 2015.

[5] T. Morton. Earth Masonry: Design and Construction Guidelines. IHS BRE Press, Bracknell, Berks., 2008.

[6] V. Kovářro. Hliněný dům, problematika jeho památkové obnovy a využití. In Zděná Architektura $v$ Čechách, Na Moravě a ve Slezsku, pp. 31 - 33. 2004.
[7] V. Hájek. Lidová stavení: opravy a úpravy. Stavitel. Grada, Praha, 1st edn., 2001.

[8] I. Žabičková. Přestavby hliněných budov. Sdružení hliněného stavitelství, Brno, 2009.

[9] J. Růžička. Building structures in environmental context, mechanical physical properties of unburned bricks by impact of humidity. Mezinárodní vědecký seminár Zdravé domy 2005.

[10] C. Sjostorm. Agenda 21 pro udržitelnou výstavbu. CIB Report Publication 237. CIB, Rotterdam, 2001.

[11] M. Jokl. Teorie vnitrnního prostredí budov. Ediční středisko Českého vysokého učení technického, 2011.

[12] Q.-B. Bui, J.-C. Morel, S. Hans, P. Walker. Effect of moisture content on the mechanical characteristics of rammed earth. Construction and Building Materials 54:163-169, 2014. DOI:10.1016/j.conbuildmat.2013.12.067.

[13] P. Walker. Rammed Earth: Design and Construction Guidelines. IHS BRE Press, Watford, 2010.

[14] J. Konta. Jílové minerály Československa. Nakladatelství Čsl. akad. věd, 1st edn., 1957.

[15] Z. Weiss. Jílové minerály: Jejich nanostruktura a využití. Karolinum, vyd. 1. edn., 2005.

[16] Q. B. Bui, J. C. Morel, B. V. Venkatarama Reddy, W. Ghayad. Durability of rammed earth walls exposed for 20 years to natural weathering. Building and Environment 44(5):912-919, 2009. DOI:10.1016/j.buildenv.2008.07.001

[17] I. Zabalza Bribián, A. Valero Capilla, A. Aranda Usón. Life cycle assessment of building materials: Comparative analysis of energy and environmental impacts and evaluation of the eco-efficiency improvement potential. Building and Environment 46(5):1133-1140, 2011. DOI:10.1016/j.buildenv.2010.12.002. 